\title{
Knowledge and Attitude of Family Physicians Regarding Adult Vaccination
}

\author{
Zeynep Baykan ${ }^{1}$, Melis Naçar ${ }^{1}$, Serap Bor Özdemir ${ }^{2}$, Serpil Poyrazoğlu ${ }^{2}$, Fevziye Çetinkaya ${ }^{3}$ \\ ${ }^{1}$ Department of Medical Education, Erciyes University School of Medicine, Kayseri, Turkey; ${ }^{2}$ Public Health Specialist, Local Health \\ Authority, Kayseri, Turkey; ${ }^{3}$ Department of Public Health, Erciyes University School of Medicine, Kayseri, Turkey. \\ Email: zbaykan@erciyes.edu.tr
}

Received March 16 ${ }^{\text {th }}, 2011$; revised May 16 ${ }^{\text {th }}, 2011$; accepted July $13^{\text {th }}, 2011$.

\begin{abstract}
Objective: The aim of this study was to establish the knowledge and attitude of family physcians offering primary health care, towards adult vaccination and their own vaccination coverage. Methods: This descriptive study was performed in May 2009 in Kayseri, Turkey. 282 family physician accepted to fill a questionnaire about adult vaccination. Results: Most of the family physcians (83.0\%) thought adult vaccination as a modality of protection and $66.7 \%$ wanted a vaccination scheme just like the one in childhood. Their own vaccination rate for Hepatitis B was $67.0 \%$ and $58.5 \%$ for influenza at any time. Only half of the physcians were vaccinated within the season for influenza. Only $9.2 \%$ of the doctors have stated that they ask questions to their patients about their vaccination status. When physcians were questioned about the vaccines they advise to their patients aged 65 and more; $70.6 \%$ stated influenza and $39.7 \%$ stated pneumococcus. Conclusions: In spite of being in the risk group, family physicians have low vaccination coverage rates. Suggestion of the necessary vaccines to the risk groups or to their patients at risk is low as well.
\end{abstract}

Keywords: Adult Vaccination, Health Personnel, Family Physician, Attitude, Knowledge

\section{Introduction}

Specially in the recent years, adult vaccination has gained as much attention as childhood vaccination nationwide and worldwide. Many studies have been performed with a variety of suggestions regarding adult vaccination [1-4]. But still, vaccination is not seen as a part of adult health care services, and adult vaccination programs are not as effective and as approachable as they are in childhood $[4,5]$. Lack of knowledge in physicians and in society, preoccupations concerning the efficacy and side effects of vaccins, not being under the coverage of health insurance, the lack of a national health policy regarding adult vaccination and the economic cost that it brings to the government can all be considered as reasons for insufficient adult vaccination [6-8].

In our country, until very recently vaccination has been considered as a special procedure for children, and apart from some exceptional cases and individual applications, adult vaccination has been neglected. Planning, coordination and continuity in administration are all very important issues in obtaining success [4]. Increasing the awareness of physicians, in other words, dealing with the lack of knowledge, which is accepted as one of the rea- sons for insufficient adult vaccination, and implementing them to give the necessary importance, will provide success in adult vaccination. physicians should evaluate the adults they see in hospitals or polyclinics, whether healthy or ill, regarding immunization against preventable diseases. They should not miss the opportunity of completing missing vaccines, they should inform the patients about the diseases and the importance of vaccination. According to the guidelines that Turkish Infectious Diseases and Clinical Microbiology Specialists Association has prepared, the vaccines that could be administered to adults are diphteria, tetanus, rubella, rubeola, mumps, influenza, pneumococcus, hepatitis A, hepatitis B, varicella, and meningococcus [9]. Vaccines that should be administered at risky situations have also been stated in this guideline. Physicians have a high probability of being exposed to these preventable diseases and the risk of infecting their patients is also high, this renders their vaccination coverage to be even more important.

Under this condition, this study was carried out to establish the knowledge and attitude of family physicians offering primary health care, towards adult vaccination and their own vaccination coverage. 


\section{Materials and Method}

This descriptive study was performed in May 2009, comprised the family physicians working in the province of Kayseri. A total of 354 family physicians working in the province were included in the study, and 282 (79.7\%) accepted to answer the questionnaire. The aim of the study was explained before an educational meeting directed by the Provincial Directorate of Health, and after getting their verbal consent, the questionnaires were filled under the surveillance of the investigators. The institutional ethics committee of Erciyes University approved this study.

Apart from the questions revealing the descriptive characteristics, their vaccination coverage, their relatives vaccination coverage, which adult vaccines they knew, and their attitude towards suggesting them to their patients were all inquired. To establish which vaccines they would suggest, they were asked to write the vaccines in some given situations. The 2009 report from the Center of Disaease Control and Prevention (CDC) was taken into account in the preparation of the questions regarding risk factors and the age at which the vaccinations should be applied [4].

Statistical analyses were conducted with the SPSS version 15.0 for Windows (SPSS Inc., Chicago, IL, USA). Data were shown as number and percents. For the comparison of categorical data Pearson chi-square or Fischer exact tests were used. $P<0.05$ was accepted as significant.

\section{Results}

The mean age of the physicians in the study group was $39.7 \pm 5.8,67.7 \%$ male, $89.9 \%$ married and, $53.6 \%$ had a work experience of 15 years and above. Out of 280 family physicians $80.0 \%$ had stated of working in a primary health care setting before. The percentage distirubition of attitude and behaviour of family physicians regarding adult vaccination was shown in Table 1. Thirty one (11.0\%) stated that they had never been vaccinated. Of the physicians that stated they had got an influenza vaccine, only $57.6 \%$ had been vaccinated in this season. There was no significant difference in vaccination according to age ( $p$ $>0.05$, chi-square $=4.312)$ and gender $(p>0.05$, Fisher exact test). Vaccination rate in male was $56.0 \%$ and $63.7 \%$ in female physicians. Fourty eight physicians started they had a chronic disease. Among the 15 physicians stating that they had diabetes, only six had got an influenza vaccination, and only three of them had a repeat dose during this season. Two of the physicians with diabetes had got a vaccination for pneumococcus. Of the 21 physicians with pulmonary, cardiac or liver disease, $47.6 \%$ (10 physicians) have stated that they had got an influenza vaccination and $70.0 \%$ of these physicians had it within this season. Only two of these physicians $(9.5 \%)$ had a pneumococcus vaccination.

Of all the group $67.0 \%$ stated they had been vaccinated against hepatitis B and $7.1 \%$ stated that they had spontaneous immunization. One hundred and eighty four (65.2\%) physicians stated that they had been vaccinated against tetanus and 145 of them remembered the timing, of these $96.6 \%$ had got a vaccine within the previous ten years. There were three physicians vaccinated against HPV, two married, one single, aged 26 and 31, and one did not state the age.

The most suggested vaccine by physicians was hepatitis B, and the least suggested one was HPV. There was also no statistically significant difference between gender and suggesting HPV vaccination $(p>0.05$, Fisher exact test).

Some aspects of the knowledge, attitude and conduct of the physicians regarding adult vaccination is given in Table 2. The vaccinations they wanted to be included into the routine program were; tetanus $(27.7 \%)$, influenza (22.0\%), pneumococcus (17.4\%) and HPV (9.6\%). 23.4\% of the physicians said that their knowledge about adult vaccination was not sufficient. Tables $\mathbf{3}$ and $\mathbf{4}$ show the vaccines suggested to some risk groups and to some disease groups by the family physicians and the opinions of physicians about the main reason regarding the low adult vaccination rates in our country are shown in Table 5.

\section{Discussion}

The risk of health personel of being exposed to diseases preventable by vaccination and of infecting their patients is substantially high. For this reason many health authorities and organizations suggest routine vaccination for health personel $[4,10]$. Health personel should get a repeat dose of Tdap, and their immunity to rubella-rubiolamumps and varicella should be complete. All people dealing with blood and blood products should be vaccinated against hepatitis B, and every health personel should get an influenza vaccination. Apart from these, some other vaccinations are administered in special situations [11].

Influenza vaccination is suggested to the health personel by CDC, since 1980's. The mainstay of this suggestion is that sick health personel pose the risk of infecting patients at work, and in places with non-vaccinated health personel, hospital born influenza epidemics can be seen [12-14]. Vaccination of health personel decreases patient morbidity and mortality and days out of work, and provides economic contribution to healthcare organizations $[15,16]$. Many worldwide programs are introduced in order to increase the vaccination rates in health personel 
Table 1. Attitude and behaviour of family physicians regarding adult vaccination.

\begin{tabular}{cccc}
\hline Vaccine & $\begin{array}{c}\text { Having } \\
\text { vaccine }\end{array}$ & $\begin{array}{c}\text { Vaccinate the first } \\
\text { degree relatives }\end{array}$ & $\begin{array}{c}\text { Suggestion } \\
\text { to the } \\
\text { patient }\end{array}$ \\
\hline Influenza & 58.5 & 46.8 & 84.8 \\
Hepatitis B & 67.0 & 33.7 & 94.7 \\
Pneumococcus & 4.3 & 10.3 & 65.2 \\
Tetanus & 65.2 & 15.6 & 61.3 \\
HPV & 3.3 & 1.1 & 36.2 \\
\hline
\end{tabular}

Table 2. Some aspects of the knowledge, attitude and conduct of the study group regarding adult vaccination.

\begin{tabular}{ccc}
\hline & Number & $\%$ \\
\hline $\begin{array}{c}\text { Vaccinating adults is a modality of protection. } \\
\text { like the one in childhood. }\end{array}$ & 234 & 83.0 \\
$\begin{array}{c}\text { There has to be a vaccination scheme for adults, } \\
\quad\end{array}$ & 188 & 66.7 \\
$\begin{array}{c}\text { There is no need to establish antibody levels } \\
\text { before hepatitis B vaccination. }\end{array}$ & 35 & 12.4 \\
$\begin{array}{c}\text { I question each of my patients about vaccina- } \\
\text { tion coverage while examining them. }\end{array}$ & 26 & 9.2 \\
$\begin{array}{c}\text { I question the pregnants about vaccination } \\
\text { coverage during examination. }\end{array}$ & 140 & 49.6 \\
$\quad \begin{array}{c}\text { I question patients } 65 \text { years old and above } \\
\text { about vaccination coverage during examination. }\end{array}$ & 52 & 18.4 \\
$\begin{array}{c}\text { I question the patients at risk about vaccination } \\
\text { coverage during examination. }\end{array}$ & 194 & 68.8 \\
$\begin{array}{c}\text { I find my knowledge about adult vaccination to } \\
\text { be insufficient. }\end{array}$ & 66 & 23.4 \\
\hline
\end{tabular}

Table 3. The distribution of the vaccines suggesed to some risk groups by the family physicians.

\begin{tabular}{|c|c|c|}
\hline & Number & $\%$ \\
\hline \multicolumn{3}{|l|}{ Aged 65 and more } \\
\hline Influenza & 199 & 70.6 \\
\hline Pneumococcus & 112 & 39.7 \\
\hline Hepatitis B & 16 & 5.7 \\
\hline Tetanus & 9 & 3.2 \\
\hline Meningokok & 6 & 2.1 \\
\hline Hepatitis A & 1 & 0.4 \\
\hline Polio & 1 & 0.4 \\
\hline \multicolumn{3}{|c|}{$\begin{array}{l}\text { Live with or provide care for a child } \\
\text { younger than age } 5\end{array}$} \\
\hline Influenza & 98 & 34.8 \\
\hline Hepatitis B & 94 & 33.3 \\
\hline Pneumococcus & 41 & 14.5 \\
\hline Meningococcus & 18 & 6.4 \\
\hline Tetanus & 14 & 4.2 \\
\hline Hepatitis A & 11 & 3.9 \\
\hline $\mathrm{Hib}$ & 6 & 2.1 \\
\hline BCG & 2 & 0.7 \\
\hline \multicolumn{3}{|l|}{ Pregnant } \\
\hline Tetanus & 217 & 77.0 \\
\hline Hepatitis B & 79 & 28.0 \\
\hline Influenza & 12 & 4.3 \\
\hline \multicolumn{3}{|l|}{ Health Personnel } \\
\hline Hepatit B & 217 & 77.0 \\
\hline Influenza & 123 & 43.7 \\
\hline Tetanus & 50 & 17.8 \\
\hline Pneumococcus & 39 & 13.8 \\
\hline Meningococcus & 12 & 4.3 \\
\hline Hepatitis A & 5 & 1.8 \\
\hline
\end{tabular}

Table 4. The distribution of the vaccines suggesed to some disease groups by the family physicians.

\begin{tabular}{lcc}
\hline & Number & $\%$ \\
\cline { 1 - 2 } $\begin{array}{l}\text { Have a health problem, such as lung, heart, } \\
\text { kidney or blood, having a disease that affects }\end{array}$ & & \\
the immun system & & \\
\hline Influenza & 151 & 53.5 \\
Pnömokococcus & 144 & 51.1 \\
Hepatitis B & 55 & 19.5 \\
Meningococcus & 15 & 5.3 \\
Diabetes mellitus & & \\
Influenza & 143 & 50.7 \\
Pnömococcus & 99 & 35.1 \\
Hepatitis B & 57 & 20.2 \\
Meningococcus & 5 & 1.8 \\
Hepatitis A & 4 & 1.4 \\
Chronic liver disease & & \\
Hepatitis B & 75 & 26.6 \\
Influenza & 61 & 21.6 \\
Pnömococcus & 48 & 17.0 \\
Meningococcus & 5 & 1.8 \\
Hepatitis A & 4 & 1.4 \\
Tetanus & 4 & 1.4 \\
Patients on kidney dialysis & & \\
Hepatitis B & 139 & 49.3 \\
Influenza & 65 & 23.0 \\
Pnömococcus & 63 & 22.3 \\
Meningococcus & 11 & 3.9 \\
Tetanus & 11 & 3.9 \\
Hepatitis A & 5 & 1.8 \\
\hline
\end{tabular}

Table 5. The opinions of the study group regarding the low adult vaccination rates in our country.

\begin{tabular}{ccc}
\hline & Number & $\%$ \\
\hline $\begin{array}{c}\text { Physcians are not informing their patients about } \\
\text { adult vaccination because they do not have } \\
\text { enough time. }\end{array}$ & 126 & 44.7 \\
$\begin{array}{c}\text { Physcians are prioritizing treatment. } \\
\text { Patients refusal of vaccination. }\end{array}$ & 81 & 28.7 \\
Physcians are not being sufficiently informed & 67 & 23.7 \\
about the topic. & 61 & 21.6 \\
Physcians ' disbelief in adult vaccination. & 48 & 17.0 \\
Others. & 40 & 14.2 \\
\hline
\end{tabular}

but surprisingly, their is a resistance. In studies performed in various countries, the influenza vaccination rates in health personel was below $50 \%$ [17-22]. In our study the rate of having been vaccinated in any season was $58.5 \%$ and the ones that were vaccinated this season were only half of these. Further studies should be planned for investigating the reasons why physicians do not get vaccinated for influenza.

Vaccination rate for influenza was higher in female physicians compared to male physicians in our study, but the difference was not significant. In a study peformed by Abramson, this rate was higher in males, but again no significant difference was found [6].

Blood born infectious diseases pose an occupational hazard for health workers. With a circular issued by the Turkish Ministry of Health in December 1996, "immuni- 
zation of health personel against hepatitis B" program has been started. In a study, performed with health personel that had the risk of contacting patients' blood, in 1995 in a university hospital, $37.0 \%$ of the physicians were vaccinated against hepatitis $\mathrm{B}$, and the main reason of not being vaccinated was negligence [23]. In another study performed in Isparta in 2006, vaccination rate was 55.8\% [24]. In a study performed in residents of a university hospital the vaccination rate was found to be $88.7 \%$ [25]. In studies from USA and France the rate was around $80 \%-90 \%$ [26,27]. In our study $67.0 \%$ of the physicians stated that they were vaccinated against hepatitis B. The rate of spontaneous immunization was $7.1 \%$ (Table $\mathbf{1}$ ). The reason our rates are not as high might be that the physicians working in the field feel that they are under lower risk compared to the physicians working in hospitals.

When the physicians were questioned about the vaccinations they suggested to health personel, the first three vaccinations were; hepatitis, influenza and tetanus (Table 3). Hepatitis B and influenza are the vaccinations strictly suggested for health personel by the Advisory Committee on Immunization Practices (ACIP). The suggestion rates were low in our study. Studies performed in health personel show that the vaccination rates increase with campaigns and vaccinations made free of charge [26,28]. Results from our study, the low vaccination coverage rates among physicians and the low suggestion rates to health personel, point to the necessity of nationwide arrangements in order to increase the vaccination rates in health personel.

Physicians have stated that the vaccination they suggested most to their patients was hepatitis B and influenza, with a rate of $94.7 \%$, and $84.8 \%$ respectively (Table 1). In spite of being in the risk group, their vaccination rates were way behind these rates. Vaccination rates of their first degree relatives were also low. These results bring into mind that, though knowledge about vaccination is sufficient, problems arise in administering them. HPV vaccination has been administered for a shorter period of time, compared to the other vaccinations, so it may not be suggested as much by the physicians.

$83.0 \%$ of the physicians in our study thought of adult vaccination as a modality of protection (Table 2 ). In a study, $90 \%$ of the physicians stated that they believed that adults should be vaccinated [29]. But in this study only $9.2 \%$ of the physicians stated that they questioned vaccination coverage in all of their patients. The inquiry rate in pregnants and patients 65 years old and above was also low. Physicians have stated that they usually question the patients they thought were under risk. Although the physicians in our study group have stated that they inquire about the vaccination coverage in the risk groups and that they thought of adult vaccination as a modality of protection, the fact that even the physicians with a chronic disease had very low vaccination coverage rates, is an inconsistent and thought-provoking result.

The performance of serologic tests to establish the HBV status is a matter of defining hepatitis B prevalence and a problem of cost-effectiveness, it is not suggested in the routine. It was stated in circular number 6856, issued by the Turkish Ministry of Health in June 1998, that "there is no need to measure the markers before and after vaccination in children and adults with normal immune systems". In our study, $77.3 \%$ of the physicians stated that they measured the antibody level before vaccination, and $7.8 \%$ that they could not because they did not have the facilities. This also can be an obstacle in adult vaccination.

When asked about their suggestions for vaccination in special situations, the rates were substantially low (Table 4). The rate of suggesting influenza to 65 years old and above was $70.6 \%$. In another study, $96.5 \%$ of the physicians stated that they suggested routinely influenza vaccination to all their patients in this age group [6]. Again, pneumococcus vaccination suggestion rates in the same age group was $39.7 \%$. Similarly, vaccination suggestion rates were low in other risk groups and in patients under risk.

Studies have established that suggestion by a doctor, has a positive impact on vaccination rates $[5,8,28]$. The most important reason behind missed opportunities for adult vaccination is the lack of the motivation physicians should provide to their patients [5]. In a study, physicians have explained that the reasons for low vaccination rates were; the refusal of patient to come in for controls, there being no reminding warning system for adult vaccination, and refusal of vaccination itself, for a variety of reasons [29]. The first three factors stated in this study were; lack of time, physicians prioritizing treatment modalities, and patients' refusal of vaccination (Table 5). Although these factors were stated as the reasons for low vaccination rates, the main factor is thought to be the physicians' lack of knowledge.

In studies performed in children, it was established that the education of health personel is effective in raising the vaccination rates [30]. Following the same strategy for adult vaccines in Turkey will surely raise the rates. Having the topic taught at school and by in-training education, knowledge will increase and with it the interest to the topic as well.

\section{Acknowledgements}

The institutional ethics committee of Erciyes University approved this study.

\section{REFERENCES}

[1] C. S. Alp, O. V. Avkan and A. Yuce, "The Seroprevalence of Diphtheria among Adults in Izmir-Turkey," Vac- 
cine, Vol. 25, No. 19, 2007, pp. 3851-3854. doi:10.1016/j.vaccine.2007.01.104

[2] Morbidity and Mortality Weekly Report, "Vaccine-Preventable Diseases: Improving Vaccination Coverage in Children, Adolescents, and Adults," A Report on Recommendations from the Task Force on Community Preventive Services, Vol. 48, No. RR-8, 18 June 1999, pp. 1-15.

[3] Centers for Disease Control, "Evidence-Based Strategies for Increasing Adult Vaccination Rates," 2011. http://www.cdc.gov/nip/publications/adultstrat.htm

[4] Türkiye Enfeksiyon Hastaliklari ve Klinik Mikrobiyoloji Uzmanlık Derneği (EKMUD) Erişkin Bağıșıklama Rehberi Çalışma Grubu, "Erişkin Bağışıklama Rehberi," Bilimsel Tip Yayinevi, 2009.

[5] P. A. Bovier, E. Chamot and G. M. Bouvier, "Importance of Patients' Perceptions and General Practitioners' Recommendations in Understanding Missed Opportunities for Immunisations in Swiss Adults," Vaccine, Vol. 19, No. 32, 2001, pp. 4760-4767. doi:10.1016/S0264-410X(01)00223-7

[6] Z. H. Abramson and O. Levi, "Influenza Vaccination among Primary Healthcare Workers," Vaccine, Vol. 26, No. 20, 2008, pp. 2482-2489. doi:10.1016/j.vaccine.2008.03.011

[7] D. Müler and T. D. Szucs, "Influenza Vaccination Coverage Rates in 5 European Countries: A Population-Based CrossSectional Analysis of the Seasons 02/03, 03/04 and 04/05," Infection, Vol. 35, No.5, 2007, pp. 308-319. doi:10.1007/s15010-007-6218-5

[8] P. R. Blank, M. Schwenkglenks and T. D. Szucs, "Influenza Vaccination Coverage Rates in Five European Countries during Season 2006/07 and Trends over Six Consecutive Seasons," BMC Public Health, Vol. 8, No. 271, 2008, pp. 1-13.

[9] Morbidity and Mortality Weekly Report, "Recommended Adult Immunization Schedule United States, 2009," Morbidity and Mortality Weekly Report, Vol. 57, No. 53, 9 January 2009.

http://www.cdc.gov/vaccines/recs/schedules/adult-schedu le.htm

[10] Recommendations of the Healthcare Infection Control Practices Advisory Committee (HICPAC) and the Advisory Committee on Immunization Practices (ACIP), "Influenza Vaccination of Health-Care Personel," Morbidity and Mortality Weekly Report, Vol. 55, No. RR02, 2006, pp. $1-16$.

[11] L. K. Pickering, C. J. Baker, G. L. Freed, S. A. Gall, S. E. Grogg, G. A. Poland, L. E. Rodewald, W. Schaffner, P. Stinchfield, L. Tan, R. K. Zimmerman and W. A. Orenstein, "Immunization Programs for Infants, Children, Adolescents, and Adults: Clinical Practice Guidelines by the Infectious Diseases Society of America," Clinical Infectious Diseases, Vol. 49, 2009, pp. 817-840. doi:10.1086/605430

[12] W. F. Carman, A. G. Elder, L. A. Wallace, K. McAulay, A. Walker, G. D. Murray and D. J. Stott, "Effects of Influenza Vaccination of Healthcare Personnel on Mortality of Elderly People in Long-Term Care: A Randomised Controlled Trial," Lancet, Vol. 355, No. 9198, 2000, pp. 93-97. doi:10.1016/S0140-6736(99)05190-9

[13] A. C. Hayward, R. Harling, S. Wetten, A. M. Johnson, S. Munro, J. Smedley, S. Murad and J. M. Watson, "Effectiveness of an Influenza Vaccine Programme for Care Home Staff to Prevent Death, Morbidity, and Health Service Use among Residents: Cluster Randomised Controlled Trial," British Medical Journal, Vol. 333, 2006, pp. 1241-1244. doi:10.1136/bmj.39010.581354.55

[14] G. A. Poland, P. Tosh and R. M. Jacobson, "Requiring Influenza Vaccination for Health Care Workers: Seven Truths We Must Accept," Vaccine, Vol. 23, 2005, pp. 2251-2255. doi:10.1016/j.vaccine.2005.01.043

[15] H. Saxen and M. Virtanen, "Randomized, Placebo-Controlled Double Blind Study on the Efficacy of Influenza Immunization on Absenteeism of Health Care Workers," Pediatric Infectious Disease Journal, Vol. 18, No. 9, 1999, pp. 779-783. doi:10.1097/00006454-199909000-00007

[16] T. D. Szucs, C. Ruef, D. Müller, E. Sokolovic, I. Beeler and W. Ostermayer, "The Economic Impact of Influenza in a University Hospital Setting," Infection Control \& Hospital Epidemiology, Vol. 22, No. 8, 2001, pp. 472-474. doi: $10.1086 / 503405$

[17] S. B. Murray and S. A. Skull, "Poor Health Care Workers Vaccination Coverage and Knowledge of Vaccination Recommendations in a Tertiary Australian Hospital," Australian and New Zealand Journal of Public Health, Vol. 26, No. 1, 2002, pp. 65-68. doi:10.1111/j.1467-842X.2002.tb00273.x

[18] K. A. Bryant, B. Stover, L. Cain, G. L. Levine, J. Siegel and W. R. Jarvis, "Improving Influenza Immunization Rates among Healthcare Workers Caring for High-Risk Pediatric Patients," Infection Control \& Hospital Epidemiology, Vol. 25, No. 11, 2004, pp. 912-917. doi: $10.1086 / 502319$

[19] F. Hofmann, C. Ferracin, G. Marsh and R. Dumas, "Influenza Vaccination of Healthcare Workers: A Literature Review of Attitudes and Beliefs," Infection, Vol. 34, No. 3, 2006, pp. 142-147. doi:10.1007/s15010-006-5109-5

[20] I. J. Takajanagi, M. R. A. Cordoso, S. F. Costa, M. E. S. Araya and C. M. Machado, "Attitudes of Health Care Workers to Influenza Vaccination: Why Are They Not Vaccinated?" American Journal of Infection Control, Vol. 35, No. 1, 2007, pp. 56-61. doi:10.1016/j.ajic.2006.06.002

[21] S. Esposito, S. Bosis, C. Pelucchi, E. Tremolati, C. Sabatini, M. Semino, P. Marchisio, F. della Croce and N. Principi, "Influenza Vaccination among Healthcare Workers in a Multidisciplinary University Hospital in Italy," BMC Public Health, Vol. 8, 2008, pp. 422-432. doi:10.1186/1471-2458-8-422

[22] P. Loulergue, F. Moulin, G. Vidal-Trecan, Z. Absi, C. Demontpion, C. Menager, M. Gorodetsky, D. Gendrel, L. Guillevin and O. Launay, "Knowledge, Attitudes and Vaccination Coverage of Health Care Workers Regarding Occupational Vaccinations," Vaccine, Vol. 27, No. 31, 
2009, pp. 4240-4243. doi:10.1016/j.vaccine.2009.03.039

[23] F. Aka and V. Dündar, "Knowledge and Attitude for Transmission Risk of Hepatitis B and HIV and Universal Precautions in Health Care Workers," Klimik Journal, Vol. 8, No. 3, 1995, pp. 114-119.

[24] İ. Demir, S. Kaya, M. Demirci and B. Arıdoğan, "Investigation of Seropositivity of Hepatitis B Virus in Healthcare Workers in Isparta, Türkiye," Turkish Journal of Infection, Vol.20, No. 3, 2006, pp. 183-187.

[25] E. Uzun, F. Akçam, E. Zengin, A. N. Kişioğlu and G. Yayli, "Evaluation of the Hepatitis B Infection Status, Knowledge and Behaviours of the Research Assistants of SDU School of Medicine," SDU School of Medicine, Vol. 5, No. 1, 2008, pp. 22-27.

[26] E. P. Simard, J. T. Miller, P. A. George, A. Wasley, M. J. Alter, B. P. Bell and L. Fellini, "Hepatitis B Vaccination Coverage Levels among Health Care Workers in the United States, 2002-2003," Infection Control \& Hospital Epidemiology, Vol. 28, 2007, pp. 783-790. doi: $10.1086 / 518730$
[27] F. Denis, V. Agabeytol and A. Aufrere, "Evaluation of Strategy and Coverage Rates for Hepatitis B Vaccination in France, a Country with Low Endemicity," Médecine et Maladies Infectieuses, Vol. 34, No. 4, 2004, pp. 149-158. doi:10.1016/j.medmal.2003.12.010

[28] K. L. Nichol, "Improving Influenza Vaccination Rates among Adults," Cleveland Clinic Journal of Medicine, Vol. 73, No. 11, 2006, pp.1009-1015. doi:10.3949/ccjm.73.11.1009

[29] D. R. Johnson, K. L. Nichol and K. Lipczynski, "Barriers to Adult Immunization," American Journal of Medicine, Vol. 121, No. 7, 2008, pp. 28-35. doi:10.1016/j.amjmed.2008.05.005

[30] E. Uskun, S. B. Uskun, M. Uysalgenç and M. Yagız, "Effectiveness of a Training Intervention on Immunization to Increase Knowledge of Primary Healthcare Workers and Vaccination Coverage Rates," Public Health, Vol. 122, No. 9, 2008, pp. 949-958. doi:10.1016/j.puhe.2007.10.005 